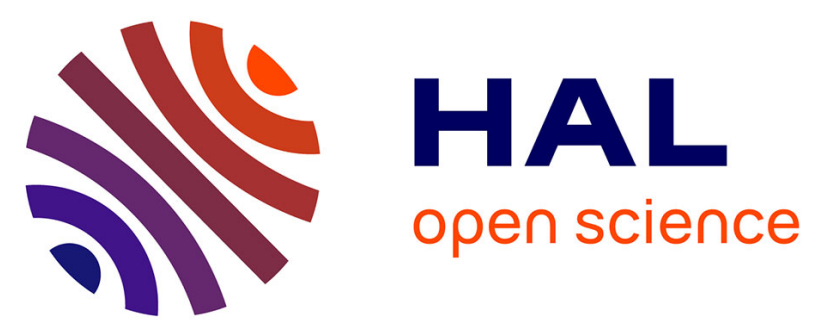

\title{
The Internalisation of Sociocultural and Thin- Ideal Standards in Sports scale: Development and preliminary validation in female athletes participating in aesthetic sports
}

Stéphanie Scoffier-Mériaux, Claude Ferrand, Fabienne d'Arripe-Longueville

\section{To cite this version:}

Stéphanie Scoffier-Mériaux, Claude Ferrand, Fabienne d'Arripe-Longueville. The Internalisation of Sociocultural and Thin- Ideal Standards in Sports scale: Development and preliminary validation in female athletes participating in aesthetic sports. International Journal of Sport and Exercise Psychology, 2016, 10.1080/1612197X.2015.1122720 . hal-02524824

\section{HAL Id: hal-02524824 \\ https://hal.univ-cotedazur.fr/hal-02524824}

Submitted on 3 Apr 2020

HAL is a multi-disciplinary open access archive for the deposit and dissemination of scientific research documents, whether they are published or not. The documents may come from teaching and research institutions in France or abroad, or from public or private research centers.
L'archive ouverte pluridisciplinaire HAL, est destinée au dépôt et à la diffusion de documents scientifiques de niveau recherche, publiés ou non, émanant des établissements d'enseignement et de recherche français ou étrangers, des laboratoires publics ou privés. 


\section{The Internalisation of Sociocultural and Thin-Ideal Standards in Sports scale: Development and preliminary validation in female athletes participating in aesthetic sports}

Stéphanie Scoffier-Mériaux $^{\mathrm{a} *}$, Claude Ferrand ${ }^{\mathrm{b}}$ and Fabienne d'Arripe-Longueville

${ }^{a}$ LAMHESS, University of Nice Sophia-Antipolis, Nice, France; ${ }^{b}$ Psychology Stages of Life (PAV), Tours University, Tours, France

(Received 1 May 2015; accepted 1 October 2015)

Thinness is a part of today's sociocultural standards of beauty and thus is implicated in bodyimage dissatisfaction and eating disorders. In female aesthetic sports, thinness is a standard for aesthetics and performance. Measuring the internalisation of thin-ideal standards in these athletes may therefore help athletes, coaches, parents, administrators, sport psychologists, and so on to gain insight into the risks associated with body-image dissatisfaction and disordered eating. This study aimed to develop and validate the Internalisation of Sociocultural and Thin-Ideal Standards in Sports (ISTISS) scale. Four studies involving 357 female aesthetic athletes examined the exploratory factorial structure, temporal stability, and concurrent validity of the ISTISS, which gave rise to a 10-item scale with two subscales: internalisation of sociocultural standards and thin-ideal standards in sports. Internal consistencies were satisfactory and relationships with the self-regulation of eating attitude in sport were as expected. These findings provide preliminary evidence for the appropriateness of the ISTISS scale for female aesthetic sports athletes.

Keywords: body norms; thinness; female aesthetic sports; self-regulation of eating attitude

\section{Introduction}

A consistent body of research has demonstrated the many negative consequences of body-image disturbance and eating pathology (e.g. decreased self-esteem, negative affect, unhealthy weight control practices, and serious medical complications) both in daily life (Stice, 2002) and the sports context (Petrie \& Greenleaf, 2008). Shroff and Thompson (2006) developed an aetiological model that is much used in the context of daily living. According to this model, parental, peer, and media influences are factors that contribute to the development of body-image and eating disturbances through the mediating roles of: (a) social comparison, (b) internalisation and (c) body dissatisfaction (Shroff \& Thompson, 2006). The authors found that the internalisation of social norms was a significant predictor of body dissatisfaction and food restriction.

In parallel, Scoffier, Maïano, and d'Arripe-Longueville (2010) showed that social relationship factors are significantly related to the eating attitudes of female aesthetic athletes through the mediating role of physical self-perceptions. However, norm internalisation has not been explored in the sports context. No valid tool is currently available. As the sports context has specific constraints and standards of achievement, a notable example being thinness in aesthetic sports (Sherman \& Thompson, 2009), an instrument is needed to measure norm internalisation in 
sports and to examine how the norms affect eating-related variables and how these variables are related.

Internalisation is the incorporation of certain values in order to conform to societal norms - for example, norms of size and appearance - to the point of modifying personal behaviour in an attempt to approximate these standards (Thompson \& Stice, 2001). Thinness is part of today's sociocultural standards of beauty and as such is related to body-image dissatisfaction and eating disorders. Indeed, "thin-ideal media" portrays thinness as a desirable trait, and most of the major protagonists in the media are thin, exceptionally beautiful, desirable, and successful (Harrison \& Hefner, 2006). Several studies have shown that the degree of thin-ideal internalisation is correlated with the severity of the eating disorder (e.g. Hawkins, Richards, Granley, \& Stein, 2004; Shroff \& Thompson, 2006).

In the sports psychology literature, several explanations have been advanced to account for the observation that adolescent athletes develop disordered eating attitudes more often than non-athletes. These young athletes are under high pressure from not only powerful media messages but also their sports environment (Kerr, Berman, \& De Souza, 2006). In the latter case, they often face high pressure to conform to an ideal body weight in order to achieve an aesthetically pleasing appearance and performance excellence, both of which may be essential to succeed (Byrne \& McLean, 2002; Sundgot-Borgen \& Torstveit, 2004). Thinness is in fact assumed to confer a competitive advantage in certain sports, and the risk of developing disordered eating attitudes is higher when low body weight contributes to speed and movement efficiency: in such sports, weight categories or aesthetic criteria require considerable self-knowledge and a specific morphology (e.g. Klinkowski, Korte, Pfeiffer, Lehmkuhl, \& Salbach-Andrae, 2008; Smolak, Murnen, \& Ruble, 2000). Female aesthetic athletes in particular seem to be at risk if they perceive that performance can be enhanced by weight regulation, and these perceptions appear to be triggered by social pressure to be thin coming from the sports environment (Krentz \& Warschburger, 2011). So athletes work towards a body required for competition and this may or may not align with what is required in their sport aesthetically. Further, this may or may not align with what is seen as ideal or desired in the athlete's social context. These athletes may become vulnerable to the unrelenting emphasis on physical appearance in aesthetic sports: they are expected to conform to a sport-specific ideal body shape and they come to believe that reaching this ideal is necessary to being attractive and successful (Sherman \& Thompson, 2009).

A widely used instrument in the general psychology literature assesses media influences and the internalisation of the ideal body shape: The Sociocultural Attitudes Towards Appearance Questionnaire-4 (SATAQ-4; Schaefer et al., 2014). The fourth version assesses the sociocultural risk factors for body dissatisfaction and eating pathology and attempts to provide a more targeted assessment of the internalisation of appearance ideals for women and men (i.e. thin and muscular ideals) and to expand the scope of the pressure subscales by including items to assess appearancerelated pressures from a variety of established sociocultural sources (i.e. peers, family, and media). However, Schaefer et al. (2014) indicated that the SATAQ-4 subscales are limited by the lack of both a discriminant validity measure and convergent validity measures, which are especially relevant for the Internalisation: Muscularity/Athletic subscale (e.g. the Drive for Muscularity Scale). The assessment of sports-specific norms is therefore not yet possible. Another current tool is the Sociocultural Internalisation of Appearance Questionnaire - Adolescents (SIAQ-A) of Kerry, Shroff, Thompson, Wertheim, and Smolak (2004). The SIAQ-A is composed of five items. It is an adaptation of the SATAQ-3 (Thompson, van den Berg, Roehrig, Guarda, \& Heinberg, 2004). The SATAQ-3 has been shown to have high internal consistency and good reliability and validity in different populations (e.g. Chinese: Jackson \& Chen, 2010; German: Knauss, Paxton, \& Alsaker, 2009; French: Rousseau, Valls, \& Chabrol, 2010). However, the 
SIAQ-A has not yet been tested in French samples. A thorough review of the available literature indicates that a French-language questionnaire evaluating norm internalisation of the thin ideal in athletes is lacking.

The current study aimed to adapt the SIAQ-A to the sports context and conduct a preliminary validation in female aesthetic sports athletes. The validation procedure followed Vallerand's (1989) recommendations: (a) study 1: develop a preliminary version and assess the clarity of the items, (b) study 2: explore the factor structure of the questionnaire, (c) study 3: confirm the factor structure of the scale, (d) study 4: assess the temporal reliability of the instrument, and (e) study 5: assess the concurrent validity of the questionnaire. In all subsequent studies, the ethics committee of the University of Nice, France, approved the protocol.

\section{Study 1: development of a preliminary version of the ISTISS}

The questionnaire was developed twice to take into account two subscales: the first related to the general norms of society and the second to the specific norms of sports. First, we transculturally validated the SIAQ-A in French following the recommendations of Beaton, Bombardier, Guillemin, and Ferraz (2000). Five steps were carried out: (a) translation, (b) synthesis of translation, (c) back-translation of the synthesis, (d) expert committee meeting with a bilingual speaker and a licensed professional psychologist expert in body-image issues to evaluate the two translations, and (e) pre-test to assess the clarity of the items.

Second, to complete this scale and adapt it to the female aesthetic sports context, we developed five items based on the original first five items. The literature relevant to understanding the female aesthetic sports standards (e.g. Sherman \& Thompson, 2009) was reviewed, and coaches from several female aesthetic sports were consulted (i.e. figure skating, dance, gymnastics). Five other items were developed in French to assess the Internalisation of Sociocultural and Thin-Ideal Standards in Sports (ISTISS). Each item was an adaptation of the French version of the SIAQ to the sports context and more especially to aesthetic sports standards. For example, the SIAQ item "I would like my body to look like the bodies of people in the movies" was adapted in the female aesthetic sports subscale as follows: "I would like my body to look like the bodies of my training partners."

\section{Assessment of ISTISS clarity}

The final pilot version was administered to 20 female adolescents ranging in age from 13 to 15 years $(M=14.25, \mathrm{SD}=1.32)$ recruited through a middle school network. If the clarity is verified among the adolescents it will be also adapted for young adults. A questionnaire with a Likert scale ranging from 1 (item not at all clear) to 6 (item quite clear) was used. The 6-point scale was chosen to remove the neutral option at the mid-point. Questionnaire completion was carried out under standardised conditions (i.e. isolation, paper, pencil) and did not exceed more than 20 minutes. Participants were informed beforehand that they were not obliged to respond and that anonymity would be maintained. They were also informed that this was not a test (i.e. there were no right or wrong answers) and that all responses would remain strictly confidential and would be used for research purposes only. Then, classroom meetings were held in order to elicit feedback on problems understanding the questionnaire items or questions about them (e. g. understanding, meaning, relevance). The descriptive statistics related to clarity showed that the total average response confirmed that the questionnaire was clear for the participants $(M=$ $4.88 ; \mathrm{SD}=.24$ ). The clarity of each item was satisfactory for the two subscales (i.e. $98.4 \%$ and $99.4 \%$, respectively). No major changes were made after this pilot study; all 10 items were retained after study 1 . 


\section{Study 2: exploratory factorial analysis of the ISTISS}

\section{Participants and procedure}

The exploration of the factorial structure was conducted with 132 female athletes competing in aesthetic sports at the national level. Athletes were eligible to participate in the study if they met the following criteria: (a) a minimum age of 12 years, (b) more than 6 hours of physical training per week, and (c) more than 4 years of sports experience. Participants were 12-22 years old $\left(M_{\text {age }}=14.58 ; \mathrm{SD}_{\text {age }}=3.06\right)$ and had been practising aesthetic sports from 6 to 18 hours per week for 7.94 years on average $\left(\mathrm{SD}_{\mathrm{nb} \text { of year }}=3.55\right)$. Three sports were represented: figure skating $(n=$ $73)$, rhythmic gymnastics $(n=41)$, and gymnastics $(n=18)$. Written consent was obtained from the training centre and the parents for minor participants. Participants were informed beforehand that the online questionnaire was not a test (i.e. there were no right or wrong answers) and that all responses would remain strictly confidential and be used for research purposes only.

\section{Data analyses}

When two or fewer items were missing, the mean value of the subscale was substituted for the missing values and if more items were missing, the participant was removed (Schafer \& Graham, 2002). In order to verify the factorial structure, principal component analysis was conducted and characterised by a varimax rotation method. Based on several indicators from this analysis, including the scree plot, eigenvalues, and proportion of variance, a two-factor solution accounting for $64 \%$ of the common variance was examined.

\section{Results}

The Kaiser-Meyer-Olkin measure of sampling adequacy yielded a score of .90. The initial scree test and eigenvalues $<1.00$ suggested two factors. Exploratory principal component analysis with varimax rotation was conducted to evaluate the initial factor structure of the ISTISS. Items were extracted one at a time according to factor loadings of less than .40 or high loading on two or more factors (Spector, 1992). No items were eliminated. These two factors accounted for $64 \%$ of the variance. The item fit was, as expected, on two factors: (a) internalisation of social physical norms and (b) internalisation of sports physical standards (see Table 1). The 10 items were examined and all showed item-total correlations greater than .40. Cronbach's alphas were .91 for the ISTISS, .88 for general norm internalisation, and .84 for athletic norm internalisation, respectively.

\section{Study 3: factorial structure of the ISTISS}

\section{Participants and procedure}

The goal of study 3 was to confirm the factorial structure of the 10 -item scale developed in study 2 in a different population through confirmatory factor analyses (CFA). To validate the scores from this scale, a different sample of female aesthetic sports athletes (i.e. figure skaters $n=79$ and dancers $n=53 ; n=132$ ), practising at the national level for figure skaters and a high level for dancers, was surveyed. Participants were $12-20$ years old $(M=16.23 ; \mathrm{SD}=2.78)$. All athletes were nationally ranked and had been training for $4-20$ hours per week $\left(M_{\mathrm{nb}}\right.$ of hours $=15.48$; $\left.\mathrm{SD}_{\mathrm{nb} \text { of hours }}=3.89\right)$ for $1_{-} 16$ years $\left(M_{\mathrm{nb} \text { of year }}=6.57 ; \mathrm{SD}_{\mathrm{nb} \text { of year }}=3.57\right)$.

\section{Data analyses}

When two or fewer items were missing, the mean value of the subscale was substituted for the missing values and if more items were missing, the participant was removed (Schafer \& 
Table 1. Results of the principal component analysis.

\begin{tabular}{lll}
\hline & Component \\
\cline { 2 - 3 } & 1 & 2 \\
\hline IN7 - J'aimerais ressembler aux personnes que je vois dans les magazines (I would & .88 & .04 \\
like my body to look like the bodies of people in the magazines) & .83 & .08 \\
IN3 - Regarder les mannequins dans les magazines me donne envie de changer mon & .83 \\
apparence (Looking at magazines makes me want to change the way I look) & .81 \\
IN9 - Lire des magazines me donne envie de changer mon apparence (Reading & .10 \\
magazines makes me want to change my appearance) & .74 & .30 \\
IN5 - Lire des magazines me donne envie de perdre ou de gagner du poids (Reading & \\
magazines makes me want to lose or gain weight) & .68 & .07 \\
IN1 - J'aimerais que mon corps ressemble à celui des personnes que je vois dans les \\
films (I would like my body to look like the bodies of people in the movies) \\
IN2 - J'aimerais que mon corps ressemble à celui de mes camarades d'entraînement \\
(I would like my body to look like the bodies of my training partners) \\
IN8 - Regarder des sportif(ve)s connues à la télévision me donne envie de perdre ou \\
de gagner du poids (Looking at famous athletes on television makes me want to \\
change by losing or gaining weight) \\
IN6 - Côtoyer des sportif(ve)s de catégories supérieures me donne envie de changer \\
mon apparence (Being around athletes more highly ranked than me makes me \\
want to change my appearance) \\
IN4 - J'ai un modèle dans mon club sportif à qui j'aimerais ressembler (I have a \\
model in my sport club who I would like to resemble) \\
IN10 - J'aimerais ressembler aux sportif(ve)s que je vois dans les compétitions \\
télévisées (I would like to resemble the athletes that I see in televised events) \\
\hline
\end{tabular}

Graham, 2002). For the factorial validity, because of the significant multivariate non-normality of 205 the data (normalised skewness: 5.6; normalised kurtosis: 15.5), CFA was performed using bootstrapped maximum likelihood estimation with the AMOS 7.0 program. Assessment of model fit was based on multiple indicators: chi-square $\left(\chi^{2}\right)$, comparative fit index (CFI), Tucker-Lewis index (TLI), and root mean square error of approximation (RMSEA). Les valeurs $\geq .90$ pour le CFI et TLI sont respectivement considérées comme des indices d'ajustement satisfaisants du modèle hypothétique (Byrne, 2005; Hoyle \& Panter, 1995; Hu \& Bentler, 1999). Concernant le RMSEA, les valeurs comprises entre $\leq .08$ et $\leq .05$ sont respectivement considérées comme des indices d'ajustement satisfaisants du modèle (Byrne, 2005; Hoyle \& Panter, 1995; Hu \& Bentler, 1999).

\section{Results}

The CFA was conducted among 132 aesthetic sports competitors; the analysis assumed that: (a) the responses are split into two factors; (b) each item has a different standardised coefficient estimate 0 of the factor that it is supposed to measure and a standardised coefficient estimate 0 of the other factors; (c) the two factors are correlated; and (d) the measurement errors are uncorrelated. The results from the CFA exhibited significant bootstrapped $\chi^{2}$ values $\left(\chi^{2}=\right.$ 74.3; $\mathrm{df}=25 ; p<.05)$. The goodness-of-fit indices were acceptable: CFI $=.910, \mathrm{TLI}=.90$, and $\mathrm{RMSEA}=.06$. The non-normality of the data might indicate ceiling effects with the measure is that population. It should be assessed in future studies. For the current sample, both factors were found to be highly reliable, with Cronbach's alphas of .92 for general norm internalisation and .82 for athletic norm internalisation. The two factors, respectively, explained $34.77 \%$ and $30.11 \%$ of the variance. 


\section{Study 4: temporal stability of the ISTISS}

\section{Participants and procedure}

Study 4 tested the reliability of the ISTISS over time in female dancers using Pearson correlation coefficients and the internal consistency of the two subscales. Fifty-three female dancers previously solicited for the factorial validity assessment completed the ISTISS twice, with a five-week interval between. Participants, practising at high level, were $12-18$ years old $(M=13.22, \mathrm{SD}=1.46)$. The questionnaires were completed under the same standardised conditions as in study 1 .

\section{Results}

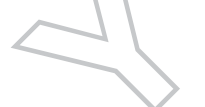

The ISTISS demonstrated adequate test-retest reliability. The Pearson product-moment correlation coefficient between the two sets of total scores (Time 1 and Time 2) was $r=.76$ ( $p$ $<.05)$. The correlation coefficients were $.73(p<.05)$ for general norm internalisation and .80 $(p<.01)$ for athletic norm internalisation, respectively. The items were also examined and revealed correlation coefficients ranging from .49 to .83 .

\section{Study 5: concurrent validity of the ISTISS}

\section{Purpose and hypotheses}

For this last study, the goal of study 5 was to test the concurrent validity of the ISTISS by examining the links between the self-regulation of eating attitudes in sports (SREAS) and the ISTISS. It was hypothesised that media influence and the internalisation of the thin ideal in the cultural contexts of France and female aesthetic sports would be negatively related to SREAS.

\section{Participants and procedure}

The sample was composed of 73 female athletes who were currently participating in an aesthetic sport (i.e. figure skating or gymnastics), competing at a national level. Participation was voluntary. Participants were $13-22$ years old $\left(M_{\mathrm{age}}=15.80 ; \mathrm{SD}_{\mathrm{age}}=2.32\right)$. They were invited by email to complete an online series of two questionnaires. For the concurrent validity of the ISTISS, we conducted correlational analysis.

\section{Measures}

This questionnaire included measures of ISTISS and SREAS. The ISTISS subscale presented good reliability and Cronbach's alphas were .90 for general norm internalisation and .87 for athletic norm internalisation, respectively. SREAS was measured with the self-reported measure that was developed and validated in French by Scoffier, Paquet, Corrion, and d'Arripe-Longueville (2010). The items were measured on a Likert-type scale ranging from 1 (not at all capable) to 6 (completely capable). A global index of SREAS was calculated by averaging the responses to items from the five subscales measuring the control of eating attitude in contexts of: (a) food temptation, (b) negative affect, (c) social interaction, (d) lack of compensatory strategy, and (e) lack of anticipation of consequences on performance. In the present study, the subscales provided good internal consistency coefficients $(\alpha>.80)$.

\section{Results}

External validity was examined in relation to SREAS and the correlational analyses indicated significant relationships in the expected directions. Indeed, the ISTISS was negatively correlated with 
Table 2. Pearson correlation scores from the concurrent validity.

\begin{tabular}{lcc}
\hline & $\begin{array}{c}r_{\text {ISSTISS }} \text { in } \\
\text { general }\end{array}$ & $\begin{array}{c}r_{\text {ISSTISS }} \text { in } \\
\text { sport }\end{array}$ \\
\hline The control of eating attitude in contexts of food temptation & $.22^{*}$ & $.34^{*}$ \\
The control of eating attitude in contexts of negative affect & $.28^{*}$ & $.36^{*}$ \\
The control of eating attitude in contexts of social interaction & $.27^{*}$ & $.30^{*}$ \\
The control of eating attitude in contexts of lack of compensatory strategy & $.28^{*}$ & $.31^{*}$ \\
The control of eating attitude in contexts of lack of anticipation of & .08 & $.30^{*}$ \\
consequences on performance & \\
\hline
\end{tabular}

${ }^{*} p<.05$.

SREAS: $r=-.33(p=.004)$. Moreover, each subscale of the ISTISS was also significantly negatively correlated with the SREAS: (a) $r_{\text {ISTISS general }}=-.27(p=.021)$ and (b) $r_{\text {ISTISS in sport }}=-.31$ $(p=.007)$. Finally, the relationships were also significant between each SREAS subscale and each ISTISS subscale, except for the correlation between the ISTISS in general and the control of eating attitude in the context of lack of anticipation of consequences on performance (Table 2).

\section{General discussion}

The development of the ISTISS was based on a widely used measure assessing media influences and the extent to which individuals internalise the thin ideal: the SIAQ-A of Kerry et al. (2004), which was translated into French. We also developed a specific subscale aimed at assessing the internalisation of the aesthetic sports thin ideal. An attempt was made to confirm the initial factor structure of the subscale and assess its reliability in a French sample of adolescent aesthetic athletes. Four studies were conducted to validate the ISTISS, involving 290 participants. The results indicated that the two theoretically defined factors were retained in the samples and displayed acceptable model fit. In sum, these results provide preliminary evidence for the appropriateness of the ISTISS scale for French female aesthetic sports athletes. Moreover, the results of the concurrent validity study were in line with the expectations suggested by previous works that reported significant associations between appearance internalisation and eating disorders (Shroff \& Thompson, 2006), and social norms and self-regulation of eating (Herman \& Polivy, 2004). Based on these preliminary results, future research could examine the mediating role of aesthetic norm internalisation in the relationship between social factors and eating-related variables to extend Schroff and Thompson's (2010) model to the sports context.

It is worth noting that the current study is limited to a specific age and gender group. Further evaluation of this instrument is warranted to establish the robustness of the present findings. Additional studies in French-speaking countries are recommended to further validate ISTISS sensitivity: (a) concerning the gender and age invariances of the factorial structure, (b) in aesthetic sports populations with reported disordered eating behaviours and (c) in individuals clinically diagnosed with an eating disorder. The measure can also be used to assess the effectiveness of interventions addressing issues related to the media, the sports culture and body image (preand post-intervention assessment). This instrument should provide significant information into eating disorder mechanisms in aesthetic athletes and new directions for prevention strategies.

\section{Acknowledgments}

The authors are grateful to the athletes and adolescents for their participation. They also sincerely thank Nina Pomes for help in the collection of the data. 


\section{Funding}

This study was financially supported by a grant from the University of Nice Sophia-Antipolis.

\section{References}

Beaton, D. E., Bombardier, C., Guillemin, F., \& Ferraz, M. B. (2000). Guidelines for the process of crosscultural adaptation of self-report measures. Spine, 25, 3186-3191.

Byrne, B. M. (2005). Factor analytic models: Viewing the structure of an assessment instrument from three perspectives. Journal of Personality Assessment, 85, 17-32.

Byrne, S., \& McLean, N. (2002). Eating disorders in athletes: A review of the literature. Journal of Science Medical in Sport, 4, 145-159. doi:10.1016/S1440-2440(01)80025-6

Harrison, K., \& Hefner, V. (2006). Media exposure, current and future body ideals, and disordered eating among preadolescent girls: A longitudinal panel study. Journal of Youth and Adolescence, 35, 146156. doi:10.1007/s10964-005-9008-3

Hawkins, N., Richards, P. S., Granley, H. M., \& Stein, D. M. (2004). The impact of exposure to the thin-ideal media image on women. Eating Disorders, 12, 35-50.

Herman, C. P., \& Polivy, J. (2004). The self-regulation of eating. In R. F. Baumeister \& K. D. Vohs (Eds.), The handbook of self-regulation: Research, theory, and applications (pp. 492-508). New York, NY: Guilford Press.

Hoyle, R. H., \& Panter, A. T. (1995). Writing about structural equation models. In R. H. Hoyle (Ed.), Structural equation modeling: Comments, issues, and applications (pp. 158-176). Thousand Oaks, CA: Sage.

Hu, L., \& Bentler, P. M. (1999). Cutoff criteria for fit indexes in covariance structure analysis: Conventional criteria versus new alternatives. Structural Equation Modeling, 6, 1-55.

Jackson, T., \& Chen, H. (2010). Factor/structure of the Sociocultural Attitudes Towards Appearance Questionnaire-3 (SATAQ-3) among adolescent boys in China. Body Image, 7, 349-355. doi:10.1016/ j.bodyim.2010.07.003.

Kerr, G., Berman, E., \& De Souza, M. J. (2006). Disordered eating patterns in elite, female gymnasts. Journal of Applied Sport Psychology, 18, 28-43. doi:10.1080/10413200500471301

Kerry, H., Shroff, H., Thompson, J. K., Wertheim, E., \& Smolak, L. (2004). The Sociocultural Internalization of Appearance Questionnaire - Adolescents (SIAQ-A): Psychometric and normative data for three countries. Eating and Weight Disorders. Studies on Anorexia, Bulimia and Obesity, 9, 56-61.

Klinkowski, N., Korte, A., Pfeiffer, E., Lehmkuhl, U., \& Salbach-Andrae, H. (2008). Psychopathology in elite rhythmic gymnasts and anorexia nervosa patients. European Child Adolescent Psychiatry, 17, 108-113. doi:0.1007/s00787-007-0643-y

Knauss, C., Paxton, S. J., \& Alsaker, F. D. (2009). Validation of the German version of the Sociocultural Attitudes Towards Appearance Questionnaire (SATAQ-G). Body Image, 6, 113-120. doi:10.1016/j. bodyim.2009.01.002.

Krentz, E. M., \& Warschburger, P. (2011). Sports-related correlates of disordered eating in aesthetic sports. Psychology of Sport and Exercise, 12(4), 375-382.

MacCallum, R. C., Browne, M. W., \& Sugawara, H. M. (1996). Power analysis and determination of sample size for covariance structure modeling. Psychological Methods, 1, 130-149.

Madanat, H. N., Hawks, S. R., \& Brown, R. B. (2006). Validation of the Sociocultural Attitudes Towards Appearance Questionnaire-3 among a Random Sample of Jordanian Women. Body Image, 3, 421425. doi:0.1016/j.bodyim.2006.09.004

McCabe, M. P., \& Ricciardelli, L. A. (2001). Parent, peer, and media influences on body image and strategies to both increase and decrease body size among adolescent boys and girls. Adolescence, 36, 225-240.

Petrie, T. A., \& Greenleaf, C. A. (2007). Eating disorders in sport: From theory to research to intervention. In G. Tenenbaum (Ed.), Handbook of sport psychology (3rd ed., pp. 352-378). Hoboken, NJ: Wiley.

Rousseau, A., Valls, M., \& Chabrol, H. (2010). The Sociocultural Attitudes Towards Appearance Scale-3 (SATAQ-3): Etude de validation de la version française. Validation of the French version of the Sociocultural Attitudes Towards Appearance Scale-3 (SATAQ-3). L'Encephale, 36, 270-276. doi:10. 1016/j.encep.2008.03.013

Schaefer, L. M., Burke, N. L., Thompson, J. K., Dedrick, R. F., Heinberg, L. J., Calogero, R. M., ... Swami, V. (2014). Development and Validation of the Sociocultural Attitudes Towards Appearance Questionnaire-4 (SATAQ-4). Psychological Assessment, 35, 293-304. doi:10.1037/a0037917. 
Schafer, J. L., \& Graham, J. W. (2002). Missing data: Our view of the state of the art. Psychological Methods, 7, 147-177. doi:10.1037//1082-989X.7.2.147

Scoffier, S., Maïano, C., \& d'Arripe-Longueville, F. (2010). The effects of social relationships and acceptance on disturbed eating attitudes in elite adolescent female athletes: The mediating role of physical self-perceptions. International Journal of Eating Disorders, 43, 65-71. doi:10.1002/eat.20597

Scoffier, S., Paquet, Y., Corrion, K., \& d'Arripe-Longueville, F. (2010). French development and validation of the self-regulatory eating attitude in sports scale (SREASS). Scandinavian Journal of Medicine \& Science in Sport, 20, 696-705. doi:10.1111/j.1600-0838.2009.00984.x

Sherman, R. T., \& Thompson, R. A. (2009). Body image and eating disturbance in athletes: Competing to win or to be thin? In J. J. Reels \& K. A. Beals (Eds.), The hidden faces of eating disorders and body image (1st ed., pp. 9-38). Reston, VA: AAHPERD.

Shroff, H., \& Thompson, J. K. (2006). The tripartite influence model of body image and eating disturbance: A replication with adolescent girls. Body Image: An International Journal of Research, 3, 17-23. doi:10. 1016/j.bodyim.2005.10.004

Smolak, L., Levine, M. P., \& Thompson, J. K. (2001). The use of the Sociocultural Attitudes Towards Appearance Questionnaire with middle school boys and girls. International Journal of Eating Disorders, 29, 216-223. doi:10.1002/1098-108X(200103)29:23.0.CO;2-V

Smolak, L., Murnen, S. K., \& Ruble, A. E. (2000). Female athletes and eating problems: A meta-analysis. International Journal of Eating Disorders, 27, 371-380.

Spector, P. E. (1992). Summated Rating Scale construction: An introduction. Beverly Hills, CA: Sage.

Stice, E. (2002). Risk and maintenance factors for eating pathology: A meta-analytic review. Psychological Bulletin, 128, 825-848. doi:10.1037/0033-2909.130.2.206

Sundgot-Borgen, J., \& Torstveit, M. K. (2004). Prevalence of eating disorders in elite athletes is higher than in the general population. Clinical Journal of Sport Medicine, 14, 25-32.

Thompson, J. K., van den Berg, P., Roehrig, M., Guarda, A. S., \& Heinberg, L. J. (2004). The Sociocultural Attitudes Towards Appearance Scale-3 (SATAQ-3): Development and validation. International Journal of Eating Disorders, 35, 293-304. doi:10.1002/eat.10257

Thompson, J. K., \& Stice, E. (2001). Thin-ideal internalization: Mounting evidence for a new risk factor for body-image disturbance and eating pathology. Current Directions in Psychological Science, 10, 181183. doi:10.1111/1467-8721.00144

Thompson, R. A., \& Sherman, R. T. (2010). Eating disorders in sport. New York, NY: Routledge.

Vallerand, R. J. (1989). Vers une méthodologie de validation transculturelle de questionnaires psychologiques: Implications pour la recherche en langue française [Towards a methodology of transcultural validation of psychological questionnaires: Implications for research in the French language]. Canadian Psychology, 30, 662-680.

Vandenberg, R. J., \& Lance, C. E. (2000). A review and synthesis of the measurement invariance literature: Suggestions, practices, and recommendations for organizational research. Organizational Research Methods, 3, 4-70. 